\title{
Needed: Some (Any!) Philosophy of Higher Education
}

\author{
DENNIS O'BRIEN
}

\section{President Emeritus, Bucknell University and University of Rochester}

Mark Taylor calls for "an end to the university as we know it." Before searching for a new model-Taylor's or anyone else's vision of tomorrow's higher learning - it is worth looking at "the beginning of the university as we know it." The "university as we know it" is actually a rather recent invention-in America about 150 years old. Historians are likely to date the current American university model from the founding of the Cornell University in 1868, Charles Eliot's reforms at Harvard in the latter half of the nineteenth century, or the opening of the John Hopkins University in 1876. Whoever takes pride of invention - and there are other claimants - the emergent and reigning model is the research university. It is that model that Taylor seeks to jettison.

The research university's prime "product" is the Ph.D. degree, an attainment not granted in the United States until 1861 at Yale. As a research degree, the $\mathrm{Ph} . \mathrm{D}$. was not just a more advanced form of the Bachelor's degrees awarded up until then by American colleges, but rather expressed a fundamentally different view of what was higher in higher education. Taylor characterizes the Ph.D. mentality accurately: specialization and sub-specialization, which leads to advance in knowledge in the chosen area. It would be bizarre to argue against the gains which the research model has brought to education and society. Because of research and research universities, we enjoy extraordinary advances in science, medicine, technology, the understanding of history, society, and even literary texts. The problem with the research model according to Taylor is, to begin with, that it produces more Ph.D.s than the market can absorb. Bad enough that the market isn't buying the product, Taylor claims further that Ph.D. research has become so refined and arcane that it may not be worth selling at all. If a sub-sub-specialist does gain a faculty berth, he or she will probably continue on a narrow path producing minimal good for society and maybe no good at all for hapless freshmen. For financial and philosophic reasons, then, the research university model needs to be "rigorously regulated and radically restructured."

(The weakest part of Taylor's argument, by the way, is that he largely ignores the natural sciences and allied fields like engineering and medicine. In those areas, specialization into seeming arcana continues to produce spectacular 
results in basic understanding and practical application, and Ph.D.s still find jobs in academia, industry, and government.)

Given this sketch of the modern university, I want to examine what the research revolution rejected. The standard American college and university before the rise of the modern university was a Christian denominational college committed to the "classical curriculum." The typical course of study consisted of a heavy dose of Greek and Latin, Paley's View of the Evidences of Christianity, lectures to the seniors by the president on ethics, and maybe some natural history if one had a collection of stuffed birds. A modern commentator notes the utter inadequacy but paradox of the classical curriculum:

The first college curriculum introduced into British America was already obsolescent, yet it became the standard one for 250 years.... In almost all official aspects the system was a failure, yet it produced a high proportion of the intellectual and political leaders of the nation.

(Earnest 1953, 1)

For a restless people forging across a continent, Cicero and Demosthenes seemed inappropriate guides. The Morrill Act of 1862, promoting the agricultural and mechanical arts, was seized upon by Ezra Cornell and Andrew Dickson White to found " a university where any person can find instruction in any subject." The practical arts and sciences entered higher education and soon eclipsed the classical curriculum and the educational philosophy of the older colleges.

To the modern academic, the classical curriculum seems "dry as dust," taught badly, with a premium put on memorization and oral recitation. No wonder the history of student life in the nineteenth century is marked by riots and destruction. The students were bored. It bears emphasizing, however, that the critic who notes the "failure" of the classical curriculum points out that these obsolete colleges "produced a high proportion of the intellectual and political leaders of the nation." Why? The classical curriculum incorporated, albeit in a particularly tedious form, the dominant philosophy of higher education for some 2000 years: the liberal arts. (Professional schools like medicine and law, which began before the rise of the universities in the thirteenth century, are another story.)

In his brilliant book Four Cultures of the West, John W. O'Malley, S.J., distinguishes two cultures that have vied for dominance in higher education: a philosophical culture and a humanistic culture. Both cultures originate in Greece, the philosophers represented by Plato and Aristotle, the humanistic culture by, for example, Isocrates, who in 390 BCE opened a school for

(C) Equinox Publishing Ltd. 2009

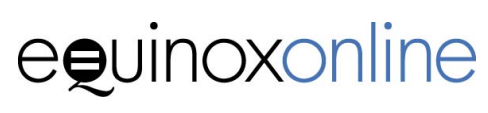


rhetoric. O'Malley characterizes the philosophic culture as "logical, rigorous, argumentative," which is the precursor of the university's scholarly style. But the longer history of higher education was in the humanistic rhetorical culture. That culture, based as it was in persuasion, supported the art of the statesman, not the scholar. That the classical curriculum produced the political leaders of the American Revolution was, then, no mere accident.

Humanistic education was, as O'Malley suggests, "classical" in two senses: it depended on a classic literature which provided models of both conduct and persuasive speech, and it was "classical" in a sense that is still with us: characterized by "balance, harmony, proportion, moderation, and rationality" (O'Malley 2004, 131). Plutarch's lives and Ciceronian rhetoric with its balanced cadences and moral passion fit the educational goals. The aim was the formation of character, a "classical" character with the traits of the literature in the curriculum: "balance, harmony, proportion, moderation, and rationality." The "rationality" alluded to is not, it should be noted, the insistent, probing "rationality" of the philosopher, but the rationality of the statesman who knows the arts of balance and harmony in his person and in political life. When Emerson in his famous Phi Beta Kappa address at Harvard in 1837 stated that "character" was the proper aim of higher education, he was asserting the essential claim of the classical curriculum.

The older classical colleges and the modern research universities differ about the ultimate purpose of higher education: formation of character versus advancement of knowledge. (A more precise description might be that character formation is a "recessive" gene in the modern university's DNA. It gets expressed in the president's speeches and all those slogans: "For God, for Country, and for Yale," "Princeton in the Nation's Service," etc. Whether these rhetorical outbursts are more than nostalgia for former days, I leave to the reader.) Mark Taylor's restructuring is toward neither character nor knowledge as such. He suggests, instead, studying notions that cross current disciplinary silos (Mind, Body) and practical problems (Water). There are, of course, problems with both suggestions. Cross disciplinary studies are not that easy because the key term is often so broad that one can't be certain that the various scholars are even talking about the same thing. Take Taylor's own principal field, religion. One of the first issues that comes up in the cross disciplinary study of religion is what constitutes a "religion." Is Confucianism a religion? Communism? As for the practical subjects, who will decide the ranking of practical issues? Which leads back to Taylor's claim that universities need to be "rigorously regulated." Maybe-but by whom?

We can gain some sense of what regulation and restructuring might look

(C) Equinox Publishing Ltd. 2009

\section{equinoxonline}


like by considering regulation and structure in earlier colleges. Rigorous regulation was exercised by the religious concerns of the sponsoring denomination. The universal acceptance of certain classic texts solidified the curriculum. Emulation of ancient republican heroes and religious saints served the ultimate aim of forming character. After the American Revolution, the classical curriculum, aimed at forming the classical virtues of moderation and balance, was regarded as a necessary support for the American experiment in democracy. Moral restraint would prevent factionalism and the enthusiasm of the mob, both of which could destroy the new republic.

The classical curriculum directed at moral instruction was expressed in structural assumptions for administration and faculty that are radically different from those in the present university. In administration, the minister college president was plenipotentiary. He hired and fired faculty and defended the curriculum. Faculty were "hired hands" and, by contemporary standards, amateurs in their special fields. Like the president himself, faculty were almost exclusively ordained ministers. If the aim of classical education was training in character, the dominance of religion and its teachers fit this aim. It was hard to imagine in those days that Christian ethics colored by classical restraint was not the perfection of moral tutelage. Then, of course, a large majority of the students were training for ministerial careers-one of the few "learned" professions of the day. There was a commonality of vocation between the faculty and the life that they expected their students would lead personally and professionally.

Regulation and structure changed radically with the advent of the research university. The principle change that affected almost everything was the rise of the faculty. In the nineteenth century, the administration in the figure of the authoritative ministerial president governed all. When the aim of education became not character but the advancement of knowledge, the faculty specialist became dominant. Tenure, a twentieth century invention, only substantiated the authority of the faculty in the research university. In the classical college, faculty were employees of the college; in the modern university faculty substantially manage the institution, though to be sure in tension with administrative "business" concerns like budgets and raising money. In brief, if the nineteenth century was the century of "management" by the authoritative president, the twentieth century became the century of faculty.

A final important change involves the relation of faculty and students. We can no longer speak of ministers training ministers; no commonality of vocation can be assumed between faculty and students. Taylor suggests, however, that in one sense current assumptions are more like the older model than one

(C) Equinox Publishing Ltd. 2009

\section{eevinoxonline}


might think. No longer do we have ministers training ministers, but specialists cloning themselves. Unhappily, most undergraduates follow careers only tangentially related to their departmental majors, and the few who go on for Ph.D.s in some specialty often won't find academic positions commensurate with their training.

If there is to be "rigorous regulation" and "radical restructuring" ahead, we are obviously not going to return to the aims, regulation, and structures of the denominational college and the classical curriculum The old style college was, however, clear about who regulated, for what end, and how that affected faculty and curriculum. The most important lesson of the classical college for the present day is its clear sense of an educational mission that goes beyond the excellences of the specific subjects taught. You taught Greek not to perfect the pluperfect but to offer moral guidance. If the research model based on the advancement of knowledge is to be sharply altered, what will be the nonspecialist educational goal that regulates and restructures? Taylor's proposal to create "problem-centered programs" presents a non-specialist goal for the university enterprise, and it may suffice. But a critical problem is whether the research university, given its current managerial and faculty assumptions, can formulate any overall educational goal beyond specialization. Lacking an educational goal, the university will inevitably be regulated and restructured by economics.

The small classical college with its lofty but limited aim and its "amateur" faculty who could slip from pulpit to professorship and back again was relatively inexpensive. The modern "multiversity" with its collection of specialties and specialists needing sophisticated and costly equipment and staff support is inherently expansive and expensive. Great discoveries may lie ahead, but funding sources may well not be forthcoming to match such hopes and ambitions. The current recession only underlines the long-term reality. If economics dominates, the twenty-first century will be like the nineteenth: a century of management-but monetary, not ministerial.

In a recent set of short commentaries in The Chronicle of Higher Education (July 19, 2009), various faculty members were asked to predict what the university would be like in twenty years. The headline caught the spirit of the comments: "The Future of the Faculty: Leaner, Meaner, More Innovative, Less Secure." With varying degrees of dismay, the faculty commentators bewailed the increasing power of administration at the price of faculty prerogative. Faculty griping about administration is old hat, but faculty need to do more than gripe. If economics is not to conquer education, modern faculties, separated as they are in terms of interests and needs, will have to agree

(C) Equinox Publishing Ltd. 2009

\section{equinoxonline}


on some overall educational vision for the university that goes beyond disciplinary specialization. If they do not create such a unitary vision, money will manage. Taylor's "rigorous regulation" and "radical restructuring" will occur, but it will not be "innovative," and instead only "leaner and meaner."

\section{References}

Earnest, Ernest

1953. The Academic Procession. Indianapolis: Bobbs-Merrill.

O’Malley, S.J., John W.

2004. Four Cultures of the West. Cambridge, MA: Harvard University Press.

(C) Equinox Publishing Ltd. 2009 